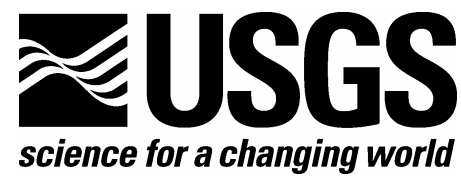

In Cooperation with National Park Service, Point Reyes National Seashore

\title{
Investigation of Wind and Water Level for the Giacomini Wetland Restoration Project, Point Reyes National Seashore
}

By John R. Dingler and Roberto J. Anima

2007

Open-File Report 2007-1151 


\section{U.S. Department of the Interior \\ DIRK KEMPTHORNE, Secretary}

\section{U.S. Geological Survey \\ Mark D. Myers, Director}

\section{U.S. Geological Survey, Reston, Virginia 2007}

For product and ordering information:

World Wide Web: http://www.usgs.gov/pubprod

Telephone: 1-888-ASK-USGS

For more information on the USGS - the Federal source for science about the Earth, its natural and living resources, natural hazards, and the environment:

World Wide Web: http://www.usgs.gov

Telephone: 1-888-ASK-USGS

Suggested citation:

Dingler, John R., and Anima, Roberto J., 2007, Investigation of wind and water level for the Giacomini wetland r estoration project, Point Reyes National Seashore: U.S. Geological Survey Open-File Report 2007-1151

[http://pubs.usgs.gov/of/2007/1151/].

Any use of trade, product, or firm names is for descriptive purposes only and does not imply endorsement by the U.S. Government.

Although this report is in the public domain, permission must be secured from the individual copyright owners to reproduce any copyrighted material contained within this report. 


\section{Contents}

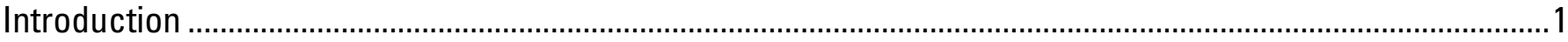

Setting

Wind

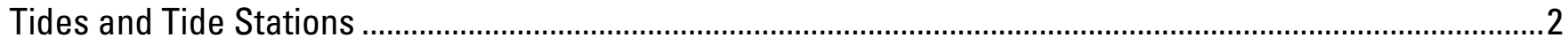

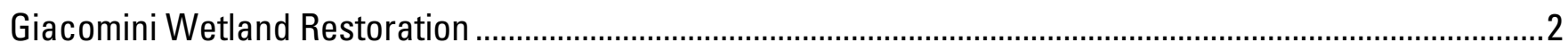

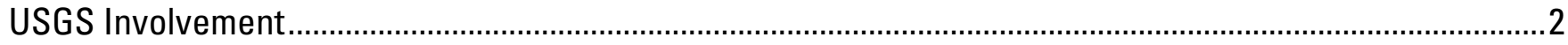

Instrument Installation and Operation ..................................................................................................

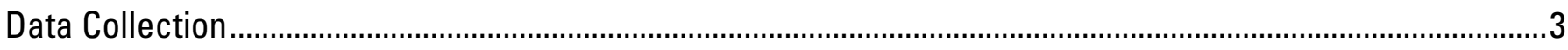

Wind

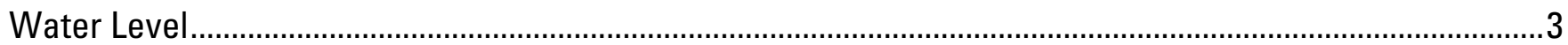

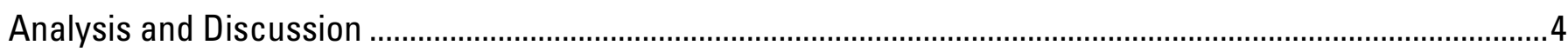

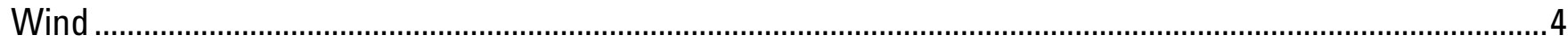

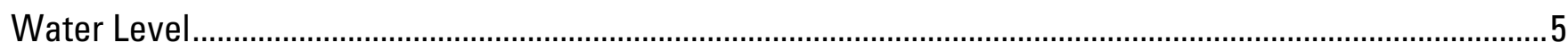

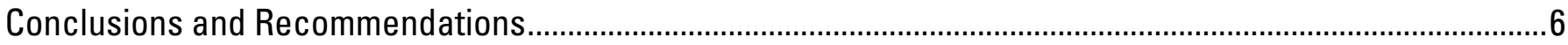

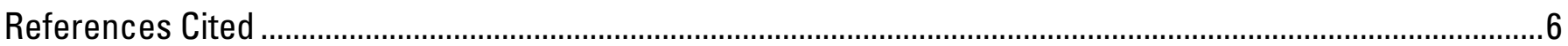

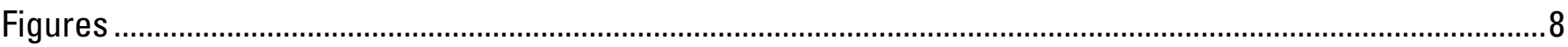

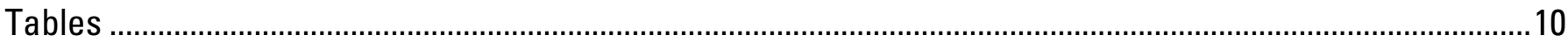

\section{Figures}

Figure 1. Point Reyes National Seashore...............................................................................................

Figure 2. Topographic map of Point Reyes National Seashore and Tomales Bay with instrument locations

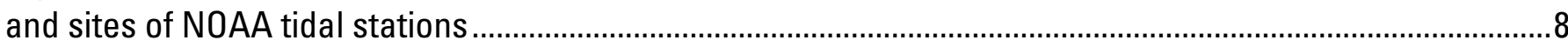

Figure 3. Meteorology tower and water-level recording station on the Giacomini levee .................................. 8

Figure 4. Sampling times for the Giacomini Levee meteorology station ........................................................ 8

Figure 5. Polar scatterplot showing wind speed as a function of wind direction by month at the Giacomini

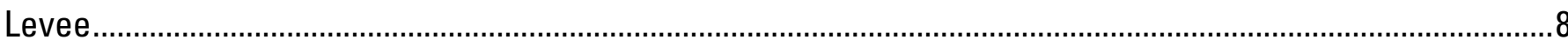

Figure 6. Polar graph showing mean resultant length for wind direction at the Giacomini Levee ....................8

Figure 7. Polar histogram showing wind speed as a function of wind direction at the Giacomini Levee .........8

Figure 8. Polar scatterplot showing wind speed as a function of wind direction at the Giacomini Levee........8

Figure 9. Water level measurements in December 2002 at the Point Reyes Tidal Station, Sacramento Landing, and Giacomini, and the predicted tide at the Point Reyes Tidal Station.............................................8

Figure 10. Water level measurements in December 2004 at the Point Reyes Tidal Station, Sacramento Landing, and Giacomini, and the predicted tide at the Point Reyes Tidal Station.............................................

Figure 11. One year of water-level measurements at Giacomini Levee and Sacramento Landing ....................8

Figure 12. Quantile plots of water level at the Giacomini Levee and Sacramento Landing versus that at the Point Reyes Tidal Station. 


\section{Tables}

Table 1. Tidal elevations for 9415020 (Point Reyes, Calif.) ................................................................................10

Table 2.Spreadsheet array of available data from the Giacomini Levee meteorology station.......................10

Table 3. Spreadsheet array of available data from the Giacomini Levee and Sacramento Landing water

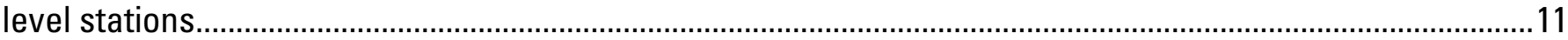

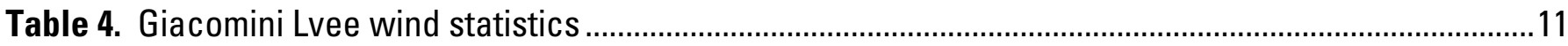

Table 5. Giacomini Levee water-level percentiles for four dates .................................................................12 


\title{
Investigation of Wind and Water Level for the Giacomini Wetland Restoration Project, Point Reyes National Seashore
}

\author{
By John R. Dingler and Roberto J. Anima'
}

\section{Introduction}

\section{Setting}

Point Reyes National Seashore (PRNS), comprising unique elements of geological, biological, and historical interest, is located on the central California coast approximately $60 \mathrm{~km}$ northwest of San Francisco (fig. 1). The National Seashore contains nearly $130 \mathrm{~km}$ of exposed and protected shorelines, spectacular coastal cliffs and headlands, lagoons, open grasslands, bushy hillsides, and forested ridges. Approximately $30 \mathrm{~km}$ of the shoreline are coastal-dune habitat that supports 11 federally listed species, including the threatened western snowy plover and the endangered plants Tidestrom's lupine (Lupinus tidestromii) and beach layia (Layia carnosa). The San Andreas Fault, a right-lateral strike-slip fault, trends northwest along the northeastern side of the park.

Tomales Bay (fig. 2), which is straight, long, narrow, and shallow, runs along the northeastern boundary of PRNS. The Bay, which fills the northwestern end of a rift valley at the intersection of the San Andreas Fault with the coastline, is approximately $20 \mathrm{~km}$ long, $2 \mathrm{~km}$ wide, and $6 \mathrm{~m}$ deep with mountainous terrain to the southwest and rolling hills to the northeast. Tomales Bay is one of the cleanest estuaries on the West Coast. In winter, approximately 17,000 to 20,000 shorebirds inhabit Tomales Bay and Bodega Bay, which lies directly to the north.

\section{Wind}

The Central California Coast lies on the eastern edge of the North Pacific high-pressure system. The location of that system throughout the year determines the predominant meteorological conditions for the region. Higher pressure offshore in combination with lower pressure in the warm inland areas results in northwesterly winds during much of the year (Mass and Bond, 1996; Renard, 1996). Normally, the high-pressure system shifts north during the summer and south during the winter. Consequently, the predominant wind direction is from the northwest between May and October (Halliwell and Allen, 1987) and from a westerly direction between November and April (Halliwell and Allen, 1987; Dorman, and others, 1995; Dorman and Winant, 1995).

In addition to the North Pacific High, migratory weather systems produce local climatic variations throughout the year. During the winter months, southeasterly to southwesterly winds form in advance of extratropical storms that cross the region. During the summer months, the

\footnotetext{
${ }^{1}$ Both at U.S. Geological Survey, Menlo Park, Calif.
} 
development of higher pressure over the interior part of the state results in offshore flow (Mass and Bond, 1996).

Land and sea breezes are a common component of the local wind regime. When the air lying over the land is cooler than the air over the ocean, a land breeze (offshore flow) develops; the reverse pattern of air temperatures generates a sea breeze (onshore flow). Typically, the land warms during the day with a maximum air-temperature difference between the ocean and valley occurring in mid afternoon. This produces a surface pressure differential between the ocean (high) and valley (low) that generates a strong, steady sea breeze. As day ends the land begins to cool, and sometime after sunset the two temperatures equalize and the wind dies. Further cooling generates a land breeze, which, in general, is weaker than the preceding sea breeze. In central California, this pattern occurs throughout the year, producing large diurnal changes in coastal weather (Banta and others, 1993).

\section{Tides and Tide Stations}

Tides along the California coast are semi-diurnal in nature (two highs and two lows a day) with a strong diurnal inequality (unequal heights in successive high or low waters). The nearest NOAA primary control tidal station used for this study is adjacent to a pier at the end of Chimney Rock Road at the western end of Drake's Bay (referred to as the 'Point Reyes Tidal Station' in this report). Both predicted water levels and measured water levels are available from NOAA for the Point Reyes Tidal Station ${ }^{2}$. Table 1 summarizes the tidal datums for that station. Only predicted water levels are available for the subordinate tide stations at Marshall and Inverness.

\section{Giacomini Wetland Restoration}

At the head of Tomales Bay, the Giacomini Ranch comprises 563 acres of pastureland currently being used for grazing dairy cattle. After more than 50 years of operation as a dairy, the National Park Service acquired the Giacomini property (fig. 2) with the intention to restore most of it and the nearby Olema Marsh to tidal wetland. Restoration will add approximately $4 \%$ to the existing coastal wetlands in California. The project will return the headwaters of Tomales Bay and two major stream intersections to an intertidal marsh environment, enhancing habitat for both wildlife and fish populations and contributing to the long-term health of Tomales Bay.

Prior to the establishment of the ranch, the area was primarily salt marsh that formed as the delta of Lagunitas Creek expanded into Tomales Bay. In converting the salt marsh to dairy land, levees and tide gates were constructed to prevent tidal incursion and stream flooding. Those levees have significantly altered the patterns of estuarine circulation and sediment deposition. To restore natural hydrologic processes within the area and to promote the return of ecological functions and processes, the levees will have to be breached or removed.

\section{USGS Involvement}

Developing a successful restoration strategy requires knowledge of elevations within the pastureland and the range of water depths that can be expected from tidal, river, and wind action. In support of the restoration program, the USGS provides technical assistance to PRNS in the form of a scientific study focusing on understanding the physical processes that could affect the Giacomini wetland restoration. The study will yield scientific products that NPS resource managers can use in designing and implementing the restoration project. Research elements include:

\footnotetext{
${ }^{2}$ http://tidesandcurrents.noaa.gov/data_menu.shtml?type=Historic+Tide+Data\&mstn=9415020
} 
- Develop a Geodetic Control Network (GCN) throughout PRNS that meets the standards specified National Geodetic Survey data base (the NGS "Bluebook"). The grid will allow this and future studies to be conducted to a precision commensurate with the expressed goals of PRNS. The survey will consist of three steps: (1) verify existing GPS control monuments in the area; (2) tie control monuments in the study areas to the GPS control monuments; and (3) establish NAVD88 elevations using a digital electronic level.

- Conduct a detailed survey of the Giacomini site to produce an accurate topographic map of the property. The site survey can be coupled with on-site water-level measurements to produce an empirical flooding model.

- Measure water level and wind regime at the Giacomini site. The water-level range is critical to determining the wetland types based on the elevation of the dairy land. Water level at Sacramento Landing, in central Tomales Bay, will also be measured for comparison.

As of November 2005, we have created a GCN, produced a detailed topographic map of the Giacomini site, and collected approximately three years of water-level and wind data at the Giacomini site and over one year of usable water-level data at the Sacramento Landing pier.

\section{Instrument Installation and Operation}

A meteorological tower and water level-gauge ${ }^{3}$ were installed on the levee adjacent to Lagunitas Creek near the bayward end of the Giacomini property (figs. 2, 3). Mounted on the 10-m tower are a suite of sensors to measure wind speed and direction, barometric pressure, air temperature, and rainfall. Cup anemometers mounted one, two, four, and eight meters above the ground and a wind direction vane mounted at the top of the tower, have threshold speeds of $1 \mathrm{~m} / \mathrm{s}$. The sample rate was $1 \mathrm{~Hz}$, and each record consisted of fifteen-minute average values and standard deviations for each sensor.

The water-level gauge uses a gas purge system to measure the water level above the tip of a small inside-diameter tube that was installed underwater in the creek. The elevation of the end of the tube was determined so that the water level can be related to a chosen datum such as NAVD88. A similar water-level gauge was mounted to the pier at Sacramento Landing (fig. 2)-using the same surveying methods to tie the elevation of the end of the tube to the NAVD88 reference point.

\section{Data Collection}

\section{Wind}

The collection of wind data at the Giacomini site started on 6 November 2002 at 1530 PST (fig. 4). The data logger samples all input channels once a second and then calculates averages for each channel at the end of the specified averaging period. Initially, the period was 10 minutes; on 6 March 2003 at 1530 PST, the period was reset to 15 minutes. All the wind data are stored in an Excel spreadsheet (column headings shown in table 2). For each sensor, successive columns represent the average and standard deviation (SD) during the sampling period

\section{Water Level}

The water level sensor measures the pressure needed to push a gas bubble out of the tube and converts that pressure to a water depth at the tip of the tube. Samples were taken every two

\footnotetext{
${ }^{3}$ Information on the instruments can be found at: http://www.nrgsystems.com/store/products.php?cd=11\&ProdGrp=STND (wind) http://www.waterlog.com/products/H355/h_355.html (water level gauge) http://www.waterlog.com/products/H350XL/H-350XL.html (water level recorder)
} 
seconds for fifteen minutes (450 samples), and the average and standard deviation of those samples recorded. At the Giacomini Levee, the tip of the tube was situated in Lagunitas Creek below MLLW. The sensor operated continuously from 13 December 2002 through 30 October 2005. Data from the period between 29 August and 22 November 2004 were lost because of a collection error. At Sacramento Landing, the tip was mounted below MLLW on a pipe attached to a pier piling. Because of fouling by marine organisms, the data were unreliable before 23 October 2004 when an effective cleaning technique was developed. Subsequent data were complete and reliable.

All of the water-level data for each location are stored in an Excel spreadsheet (column headings shown in table 3). The spreadsheet also contains the Inverness, Marshall, and Point Reyes Tidal Station predicted tides as well as the measured values at the Point Reyes Tidal Station. The corrected depth, $\mathrm{H}_{2}$, is derived by correcting the measured depth, $\mathrm{H}_{1}$, to the NAVD88 datum. $\mathrm{H}_{\mathrm{pr}}$, the measured depth from the Point Reyes Tidal Station gauge, is also based on NAVD88 assuming that datum and MLLW are the same at that station (table 1).

\section{Analysis and Discussion}

\section{Wind}

The primary goal of the meteorology measurements at the Giacomini site was to assess the affect of wind on water level especially during periods of high water when flooding of roads and property adjacent to the restored wetland was most likely to occur. Although the wind data clearly show the pattern of speed and direction and wind shear at the levee, no correlation with overall water level was found.

Wind blows primarily from the northwest and southeast with a southwest component during some times of the year (figs. 5, 6) at speeds up to $17 \mathrm{~m} / \mathrm{s}$ (figs. 7, 8). Northwest winds predominate from April through October and southeast winds from November through February with a notable southwest component between May and September (fig. 5). Northwest winds are indicative of the summer regional wind pattern for the northern Pacific, southeast winds of winter storms, and southwest winds of the summer sea breeze. The axis of Tomales Bay aligns with the predominant summer winds from the northwest and the winter storm winds from the southeast. Although it is protected from sea breezes by the mountainous topography of the Inverness Ridge, some winds reach the bay through gaps along the ridge.

Nonetheless, there is a large variability in wind direction at the Giacomini Levee that can only be quantified by the use of statistics for cyclic data (i.e., the beginning and end of the scale coincide: $0^{\circ}=360^{\circ}$ ). Because of the circular nature of directional data, the classic arithmetic mean is likely to be a poor summary statistic (e.g., the mean of $1^{\circ}$ and $359^{\circ}$ is not $180^{\circ}$ ). The equivalent circular parameter the mean resultant length, $\mathrm{R}$, defined by

$$
\mathrm{R}^{2}=\left(\mathrm{S}^{2}+\mathrm{C}^{2}\right) / \mathrm{N}^{2}
$$

$(0 \leq \mathrm{R} \leq 1)$

where $\theta$ is the wind direction and there are $\mathrm{N}$ observations, each with unit weight, and

$$
\mathrm{S}=\sum_{1}^{N} \sin (\theta) \quad \mathrm{C}=\sum_{1}^{N} \cos (\theta)
$$

If $\mathrm{R}$ not equal to zero, the circular mean, $\Theta$, is defined by

$\Theta=\arctan (\mathrm{S} / \mathrm{C})$.

As $\mathrm{R}$ approaches 1, the observed directions cluster about $\Theta$; as $\mathrm{R}$ decreases, the observed values become widely dispersed or from opposite directions, and $\Theta$ loses significance. With respect to the Giacomini Levee wind data, $\mathrm{R}$ notably varies with month and wind speed (fig. 6). 
On a monthly basis, $\mathrm{R}$ is 0.5 or greater in May and September, which are transition months between summer and winter wind patterns. In January, March, April, October, and November, $\mathrm{R}$ is between 0.25 and 0.5 . In the other months, $\mathrm{R}$ less than 0.25 . Considering wind speed categories, when $U_{8}$ is greater than or equal to $10 \mathrm{~m} / \mathrm{s}, R$ is approximately 0.5 . When $U_{8}$ is greater than $5 \mathrm{~m} / \mathrm{s}$, $\mathrm{R}$ is 0.25 .

The maximum wind speed measured at the 8-m anemometer $\left(U_{8}\right)$ exceeded $17 \mathrm{~m} / \mathrm{s}$ (table 4$)$. Wind speeds greater than $10 \mathrm{~m} / \mathrm{s}$ occur $1.2 \%$ of the time and only come out of the southeast and northwest (fig. 7) with the predominant direction being the southeast, probably as a result of winter storms (fig. 8).

\section{Water Level}

Using data from the Point Reyes Tidal Station and the water-level gauges at Sacramento Landing and the Giacomini Levee (fig. 2) allows us to look at tidal differences between the open ocean, central Tomales Bay, and the head of the bay (figs. 9, 10). Clearly, the tide is the largest contributor to the water level, as the three curves have a shape and periodicity that is consistent with a tidal cycle. The major differences are that there is a shift in the times of highs and lows between the sites and there is an elevation of the highs and truncation of the lows at Giacomini relative to the other sites. Data from the water level gauge at Sacramento Landing show a floodtide lag of approximately 2 hours between the tidal peak at Sacramento Landing and Point Reyes Tidal Station (temporal offset) and an ebb-tide lag of approximately 3 hours. Tidal ranges are approximately equal at the two locations. At the Giacomini Levee, the lag is approximately 1 hour for the flood tide and 4 hours for the ebb. Elevations are not equal; the peaks match with slightly higher elevations at the Levee, but the troughs at the Giacomini Levee are significantly truncated relative to those at Sacramento Landing (fig. 11). The truncation could be caused by an increased impact of the flow in Lagunitas Creek during the ebb tide and/or modification of the low-tide flow over the mud flat.

Quantile plots further elucidate water-level differences between the sites (figs. 12, 13). Quantiles are points taken at regular intervals from the cumulative distribution function of a random variable. Dividing ordered data into q equal-sized data subsets is the motivation for qquantiles; the quantiles are the data values marking the boundaries between consecutive subsets. Put another way, the kth q-quantile is the value $x$ such that the probability that a random variable will be less than $\mathrm{x}$ is at most $\mathrm{k} / \mathrm{q}$ and the probability that a random variable will be less than or equal to $\mathrm{x}$ is at least $\mathrm{k} / \mathrm{q}$. There are $\mathrm{q}-1$ quantiles, with $\mathrm{k}$ an integer satisfying $0<\mathrm{k}<\mathrm{q}$. Some quantiles have special names: the 100-quantiles are called percentiles and the 4-quantiles are called quartiles." In quantile scatterplots, the quantiles of one variable are plotted against the quantiles of another variable to assess the similarity of the empirical distributions of the two variables (fig. 12). If the data points fall on the regression line, then it can be concluded that the two variables follow the same distribution. Plotting each $\mathrm{H}_{\mathrm{g}}\left(\mathrm{H}_{2}\right.$ at the Giacomini Levee) and $\mathrm{H}_{\mathrm{s}}\left(\mathrm{H}_{2}\right.$ at Sacramento Landing) against $\mathrm{H}_{\mathrm{pr}}$ (water level at the Point Reyes Tidal Station) shows the difference between the water-level patterns at the Levee and Sacramento Landing. The $\mathrm{H}_{\mathrm{s}}-\mathrm{H}_{\mathrm{pr}}$ curve falls on the normal regression line except for the largest values, indicating that the peaks are higher in Tomales Bay than at the Point Reyes Tidal Station. However, the $\mathrm{H}_{\mathrm{g}}-\mathrm{H}_{\mathrm{pr}}$ curve does not match the regression line at all, and its shape indicates that both low and high water are higher at the Giacomini Levee.

In quantile-quantile plots, which are different from quantile scatterplots, the observed values of a variable are plotted against the theoretical quantiles of that variable. Such a plot would indicate a good fit of the theoretical distribution to the observed values if the plotted values fall

\footnotetext{
${ }^{4}$ Wikipedia: 7 June 2006
} 
onto a straight line. In figure 13, the deviation from a straight line in all three curves- $\mathrm{Hg}$, $\mathrm{Hs}$, and $\mathrm{Hpr}$ - is consistent with a tidal pattern. Again, the sharp deviation in the lower part $\mathrm{Hg}$ curve shows that low water is much different than would be expected from tidal action.

Water elevations over the Giacomini site after the levees are opened are based on the percentile values of the water-level data at the levee (table 5 and fig. 14). In this case, percentile values represent the amount of time the water level is above that value. Thus, the $50^{\text {th }}$ percentile, or median, value is the elevation that is exceeded $50 \%$ of the time. The minimum and maximum values are the lowest and highest water-level elevations (one data point). Contouring the topographic map using these percentile values shows the percentage of time that the water will equal or be greater than the given elevation. The map shows that most of the Giacomini Ranch site would be flooded less than $50 \%$ of the time if there were openings in the levees.

Because the wind predominantly blows along the axis of Tomales Bay, strong winds possibly could increase or decrease high water levels. For example, a strong northwest wind blowing at a higher-high tide could increase the water level over the wetland. The reverse could be true of a southeast wind. However, we found no correlation between wind and water level at the levee site when we compared wind speed with high water levels (fig. 15). Likely, any affect of wind on water level would be masked by the large tidal signal. Furthermore, the affect of creek flow is unknown and the influence of the mud flat on controlling the water level is not quantifiable with our data. Qualitatively, the strong winds that are associated with winter storms would either have no affect on water level or would push water away from the head of the bay, thus lowering the effective water level over the wetland.

\section{Conclusions and Recommendations}

The objective of this study was to gather topographic, wind, and water-level data at the Giacomini Ranch to be able to predict flooding levels if PRNS converts the property to an intertidal marsh environment. Three years of data show the property would be flooded less than $50 \%$ of the time if the levees were breached and the maximum water level would not result in flooding of adjacent property. A caveat, though, is that these data do not consider the affect of a large flood in Lagunitas Creek during times of highest water. A guess is that the increased area resulting from opening the levees would accommodate the excess water without flooding. To better evaluate the flooding affect, one would need to know the increased volume of water and how the creek and tide interact.

We recommend that the Giacomini water-level station be operated for at least two years after the levee is breached. Those data can be compared with the pre-breach data (fig. 14) to see how increasing the area exposed to tides alters maximum water levels. The wind and water-level stations could also be modified to transmit their data to the visitor center for real-time display. Besides being of public interest, such a display would alert park personnel before extreme water levels are reached.

\section{References Cited}

Banta, R.M., Olivier, L.D, and Levinson, D.H., 1993, Evolution of the Monterey Bay sea-breeze layer as observed by pulsed Doppler lidar: Journal of Atmospheric Science, v. 50, p. 39593982.

Dorman, C.E., and Winant, C.W., 1995, Buoy observations of the atmosphere along the west coast of the United States, 1981-1990. Journal of Geophysical Research, v. 100, p. 16029-16044. 
Dorman, C.E., Enriquez, A.G., and Friehe, C.A., 1995, Structure of the Lower Atmosphere over the Northern California Coast during Winter. Monthly Weather Review, v. 123, p. 2384-2404.

Halliwell, G.R., and Allen, J.S., 1987, Wavenumber-frequency domain properties of the coastal sea level response to alongshore wind stress along the west coast of North America, 1980-84. Journal of Geophysical Research, v. 92, p. 11761-11788.

Mass, C.F., and Bond, N.A., 1996, Wind Reversals along the United States West Coast during the Warm Season. Part II:Synoptic Evolution. Monthly Weather Review, v. 125, p. 1692-1694.

Renard, R.J., 1996, and earlier years, Monterey Peninsula Monthly Weather Summaries:

Unpublished documents available from Department of Meteorology, Naval Postgraduate School, Monterey, CA 93943. 


\section{Figures}

Figure 1. Point Reyes National Seashore, (box at the top left corner of the image) is approximately $60 \mathrm{~km}$ northwest of San Francisco. The San Andreas Fault trends from southeast to northwest along the northeast boundary of the National Seashore (red lines mark Bay-Area faults).

Figure 2. Topographic map of Point Reyes National Seashore and Tomales Bay with instrument locations and sites of NOAA tidal stations.

Figure 3. Meteorology tower and water-level recording station on the Giacomini levee. The tower is 10-m high with anemometers at 1,2, 4, and $8 \mathrm{~m}$ and a wind vane on top. A tube runs from the water-level box to Lagunitas Creek (background).

Figure 4. Sampling times for the Giacomini Levee meteorology station. Breaks in the line represent times of no data.

Figure 5. Polar scatterplot showing wind speed $\left(\mathrm{U}_{g^{\prime}} \mathrm{m} / \mathrm{s}\right)$ as a function of wind direction $\left({ }^{\circ} \mathrm{TN}\right)$ by month at the Giacomini Levee. For clarity the radial axis $\left(\mathrm{U}_{8}\right)$ is reversed, placing the minimum speed at the graph's circumference.

Figure 6. Polar graph showing mean resultant length for wind direction ( $\left.{ }^{\circ} \mathrm{TN}\right)$ at the Giacomini Levee. Data points represent selected averages: each month, $\mathrm{U}_{8}$ greater than $5 \mathrm{~m} / \mathrm{s}, \mathrm{U}_{8}$ greater than $10 \mathrm{~m} / \mathrm{s}$, and all the data.

Figure 7. Polar histogram showing wind speed $\left(\mathrm{U}_{8^{\prime}} \mathrm{m} / \mathrm{s}\right)$ as a function of wind direction $\left({ }^{\circ} \mathrm{TN}\right)$ at the Giacomini Levee. Wind speed is broken into four categories.

Figure 8. Polar scatterplot showing wind speed $\left(\mathrm{U}_{8^{\prime}} \mathrm{m} / \mathrm{s}\right)$ as a function of wind direction $\left({ }^{\circ} \mathrm{TN}\right)$ at the Giacomini Levee. For clarity the radial axis $\left(U_{8}\right)$ is reversed, placing the minimum speed at the graph's circumference

Figure 9. Water level measurements in December 2002 at the Point Reyes Tidal Station $\left(\mathrm{H}_{\mathrm{pr}}\right)_{\text {, }}$ Sacramento Landing $\left(\mathrm{H}_{\mathrm{s}}\right)$, and Giacomini $\left(\mathrm{H}_{\mathrm{g}}\right)$ and the predicted tide at the Point Reyes Tidal Station $\left(\mathrm{T}_{\mathrm{pr}}\right)$. (B) a two-week period; $(\mathrm{A})$ two days to dramatize the truncation of the low water at Giacomini and the temporal offsets of the highs and lows between the sites, and the strength of the tidal signal.

Figure 10. Water level measurements in December 2004 at the Point Reyes Tidal Station $\left(\mathrm{H}_{\mathrm{pr}}\right)$, Sacramento Landing $\left(\mathrm{H}_{\mathrm{s}}\right)$, and Giacomini $\left(\mathrm{H}_{\mathrm{g}}\right)$ and the predicted tide at the Point Reyes Tidal Station $\left(\mathrm{T}_{\mathrm{pr}}\right)$. (B) a two-week period; $(\mathrm{A})$ two days to dramatize the truncation of the low water at Giacomini, the temporal offsets of the highs and lows between the sites, and the strength of the tidal signal

Figure 11. One year of water-level measurements at Giacomini Levee (black) and Sacramento Landing (red). Clearly, truncation of the tidal lows consistently occurs throughout the year. 
Figure 12. Quantile plots of water level at the Giacomini Levee and Sacramento Landing versus that at the Point Reyes Tidal Station. In quantile scatterplots, the quantiles of one variable are plotted against the quantiles of another variable to assess the similarity of the empirical distributions of the two variables. If the data points fall on the regression line (red line), then it can be concluded that the two variables follow the same distribution. Clearly, the Giacomini Levee water level does not match that at the Point Reyes Tidal Station as well as the Sacramento Landing water level does.

Figure 13. Quantile-Quantile plots of water level at the Point Reyes Tidal Station $\left(\mathrm{H}_{\mathrm{pr}}\right)$, Sacramento Landing $\left(\mathrm{H}_{\mathrm{s}}\right)$, and Giacomini $\left(\mathrm{H}_{\mathrm{g}}\right)$. In quantile-quantile plots, the observed values of a variable are plotted against the theoretical quantiles. A good fit of the observed values to the theoretical distribution would be indicated if the plotted values fall onto a straight line. The curves at the ends of each of the plots represent low and high tides. The fact that the $\mathrm{H}_{\mathrm{pr}}$ and $\mathrm{H}_{\mathrm{s}}$ match indicates that water fluctuations at those sites is similar. The shift to the right in the upper part of $\mathrm{H}_{\mathrm{g}}$ suggests a slight delay in the flood cycles relative to the other sites, and the extreme variation at the lower end represents flow truncation during the ebb cycles.

Figure 14. Predicted inundation levels if the Giacomini Levees are opened. Contours are based on all available water-level data from the Giacomini Levee station. Contours are produced by colorcoding the topographic map of the property using water-level percentiles.

Figure 15. Wind speed at the Giacomini Levee, $\mathrm{U}_{8^{\prime}}$ versus water level, $\mathrm{H}_{\mathrm{g}}$. The minimum water level shown on the abscissa, $1.8 \mathrm{~m}$, corresponds to the $90^{\text {th }}$ percentile of all data $(10 \%$ of all water levels were greater than $1.8 \mathrm{~m}$ ). The data are broken out by three-month periods to better show levels during stormy and fair seasons. There is no obvious correlation. 


\section{Tables}

Table 1. Tidal elevations for 9415020 (Point Reyes, Calif.) ${ }^{4}$

Latitude: $37^{\circ} 59.8^{\prime} \mathrm{N}$, Longitude: $122^{\circ} 58.5^{\prime} \mathrm{W}$

\begin{tabular}{|l|r|}
\hline Maximum Water Level & $2.61 \mathrm{~m}$ \\
\hline Mean Higher High Water (MHHW) & $1.76 \mathrm{~m}$ \\
\hline Mean High Water (MHW) & $1.55 \mathrm{~m}$ \\
\hline Mean Tide Level (MTL) & $0.96 \mathrm{~m}$ \\
\hline Mean Sea Level (MSL) & $0.95 \mathrm{~m}$ \\
\hline Mean Low Water (MLW) & $0.36 \mathrm{~m}$ \\
\hline Mean Lower Low Water (MLLW) & $0.00 \mathrm{~m}$ \\
\hline Minimum Water Level & $-0.82 \mathrm{~m}$ \\
\hline NAVD88 Elevation & $0.01 \mathrm{~m}$ \\
\hline
\end{tabular}

Table 2. Spreadsheet array of available data from the Giacomini Levee meteorology station [SD = Standard Deviation]

\begin{tabular}{|l|l|l|l|}
\hline COLUMN & VALUE & COLUMN & VALUE \\
\hline 1 & Julian Day & 16 & (Unused) \\
\hline 2 & Date & 17 & (Unused) \\
\hline 3 & Time & 18 & Direction \\
\hline 4 & Housing Temperature & 19 & SD Direction \\
\hline 5 & Battery & 20 & (Unused) \\
\hline 6 & WIND SPEED $\left(\mathrm{U}_{1}, \mathrm{~m} / \mathrm{s}\right)$ & 21 & (Unused) \\
\hline 7 & SD $\mathrm{U}_{1}$ & 22 & (Unused) \\
\hline 8 & WIND SPEED $\left(\mathrm{U}_{2}, \mathrm{~m} / \mathrm{s}\right)$ & 23 & (Unused) \\
\hline 9 & SD $\mathrm{U}_{2}$ & 24 & Temperature \\
\hline 10 & WIND SPEED $\left(\mathrm{U}_{4}, \mathrm{~m} / \mathrm{s}\right)$ & 25 & SD Temperature \\
\hline 11 & SD $\mathrm{U}_{4}$ & 26 & Barometer \\
\hline 12 & Rain Gauge & 27 & SD Barometer \\
\hline 13 & SD Rain Gauge & 28 & (Unused) \\
\hline 14 & WIND SPEED $\left(\mathrm{U}_{8}, \mathrm{~m} / \mathrm{s}\right)$ & 29 & (Unused) \\
\hline 15 & SD $\mathrm{U}_{8}$ & & \\
\hline
\end{tabular}

${ }^{4}$ the station description is available at the NOAA website:

http://140.90.121.76/cgi-bin/station_info.cgi?stn=9415020+Point+Reyes+,+CA 
Table 3. Spreadsheet array of available data from the Giacomini Levee and Sacramento Landing water level stations

\begin{tabular}{|l|l|l|l|}
\hline COLUMN & \multicolumn{1}{|c|}{ VALUE } & COLUMN & \multicolumn{1}{c|}{ VALUE } \\
\hline 1 & Day & 6 & $\mathrm{H}_{2}$ (corrected depth, $\left.\mathrm{m}\right)$ \\
\hline 2 & Time & 7 & $\mathrm{~T}_{\mathrm{i}}$ (Inverness tide, $\left.\mathrm{m}\right)$ \\
\hline 3 & $\mathrm{H}_{1}$ (measured depth, $\left.\mathrm{m}\right)$ & 8 & $\mathrm{~T}_{\mathrm{m}}($ Marshall tide, $\mathrm{m})$ \\
\hline 4 & Julian Date & 9 & $\mathrm{~T}_{\mathrm{pr}}$ (Point Reyes tide, $\left.\mathrm{m}\right)$ \\
\hline 5 & Date & 10 & $\mathrm{H}_{\mathrm{pr}}$ (Point Reyes depth, $\left.\mathrm{m}\right)$ \\
\hline
\end{tabular}

Table 4. Giacomini Lvee wind statistics (75,869 samples at four samples per hour)

\begin{tabular}{|l|r|r|r|r|}
\hline & $\mathrm{U} 1(\mathrm{~m} / \mathrm{s})$ & $\mathrm{U} 2(\mathrm{~m} / \mathrm{s})$ & $\mathrm{U} 4(\mathrm{~m} / \mathrm{s})$ & $\mathrm{U} 8(\mathrm{~m} / \mathrm{s})$ \\
\hline MINIMUM & 0.00 & 0.00 & 0.00 & 0.00 \\
\hline $1^{\mathrm{ST}}$ PERCENTILE & 0.35 & 0.35 & 0.35 & 0.35 \\
\hline $5^{\mathrm{TH}}$ PERCENTILE & 0.35 & 0.35 & 0.36 & 0.38 \\
\hline $10^{\mathrm{TH}}$ PERCENTILE & 0.36 & 0.41 & 0.46 & 0.56 \\
\hline $25^{\mathrm{TH}}$ PERCENTILE & 0.55 & 0.83 & 1.02 & 1.26 \\
\hline MEDIAN & 1.46 & 1.88 & 2.22 & 2.54 \\
\hline $75^{\mathrm{TH}}$ PERCENTILE & 3.07 & 3.70 & 4.42 & 4.83 \\
\hline $90^{\mathrm{TH}}$ PERCENTILE & 4.36 & 5.06 & 6.08 & 6.59 \\
\hline $95^{\mathrm{TH}}$ PERCENTILE & 5.20 & 5.93 & 7.01 & 7.67 \\
\hline $99^{\mathrm{TH}}$ PERCENTILE & 6.88 & 7.75 & 9.15 & 10.26 \\
\hline MAXIMUM & 11.73 & 13.99 & 16.14 & 17.38 \\
\hline MEAN & 1.99 & 2.41 & 2.88 & 3.21 \\
\hline STANDARD DEVIATION & 1.66 & 1.87 & 2.23 & 2.41 \\
\hline STANDARD ERROR & 0.01 & 0.01 & 0.01 & 0.01 \\
\hline SKEWNESS & 1.07 & 0.96 & 0.92 & 0.95 \\
\hline KURTOSIS & 0.64 & 0.49 & 0.34 & 0.56 \\
\hline
\end{tabular}


Table 5. Giacomini Levee water-level percentiles for four dates

\begin{tabular}{|r|r|r|r|r|r|}
\hline & Percentile & 2004.08 .02 & 2004.12 .02 & 2005.05 .23 & 2005.09 .29 \\
\hline Minimum & 0 & 0.47 & 0.47 & 0.47 & 0.47 \\
\hline $1 \%$ ile & 1 & 0.53 & 0.53 & 0.54 & 0.54 \\
\hline $10 \%$ ile & 5 & 0.59 & 0.60 & 0.62 & 0.62 \\
\hline $25 \%$ ile & 10 & 0.67 & 0.67 & 0.69 & 0.69 \\
\hline Median & 25 & 0.84 & 0.85 & 0.87 & 0.86 \\
\hline $75 \%$ ile & 50 & 1.13 & 1.14 & 1.16 & 1.16 \\
\hline $90 \%$ ile & 75 & 1.45 & 1.47 & 1.48 & 1.48 \\
\hline $95 \%$ ile & 90 & 1.75 & 1.76 & 1.77 & 1.79 \\
\hline $99 \%$ ile & 95 & 1.92 & 1.94 & 1.95 & 1.96 \\
\hline Maximum & 99 & 2.20 & 2.21 & 2.22 & 2.22 \\
\hline & 100 & 2.65 & 2.65 & 2.71 & 2.71 \\
\hline Valid N & & & & & 90384 \\
\hline Mean & & 57371 & 63968 & 1.20 & 92764 \\
\hline Std.Dev. & & 1.18 & 1.19 & 0.41 & 1.20 \\
\hline Std. Err. & & 0.41 & 0.41 & 0.00 & 0.41 \\
\hline Skewness & & 0.00 & 0.00 & 0.50 & 0.00 \\
\hline Kurtosis & & 0.50 & 0.50 & -0.35 & -0.38 \\
\hline
\end{tabular}




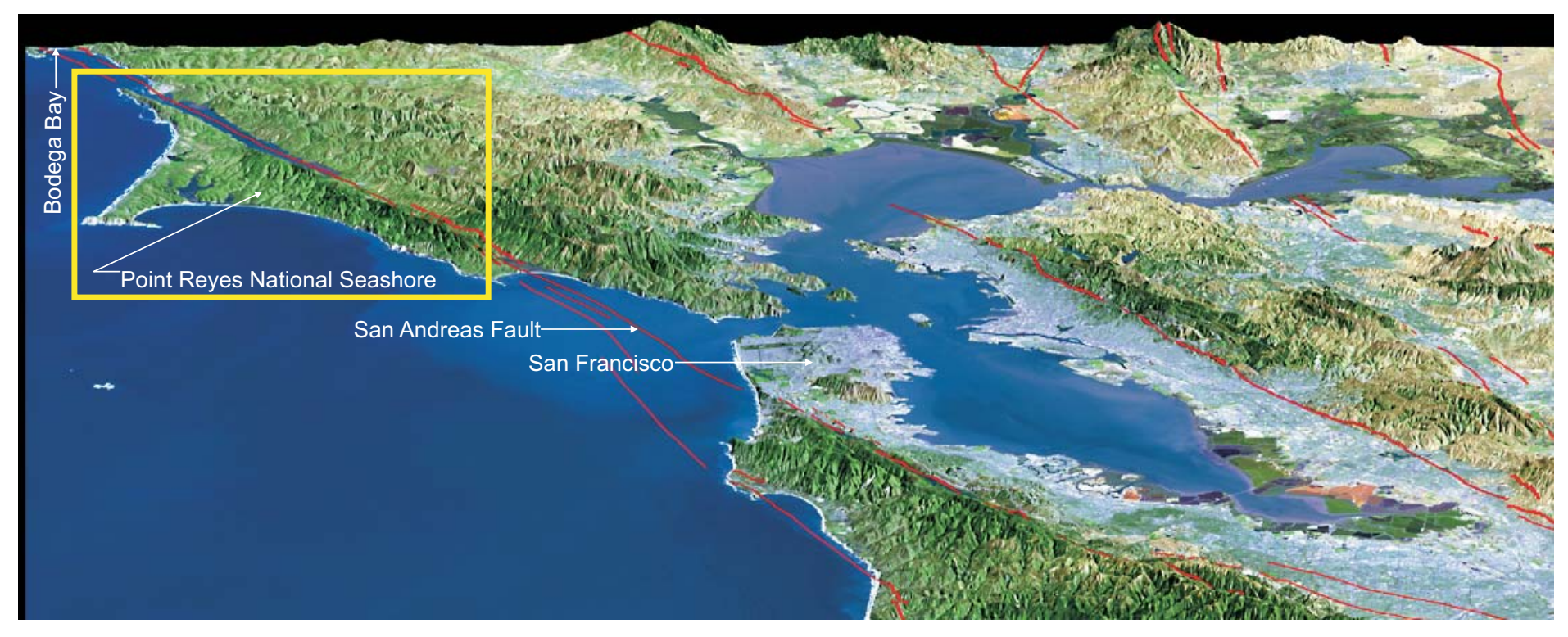

Figure 1 


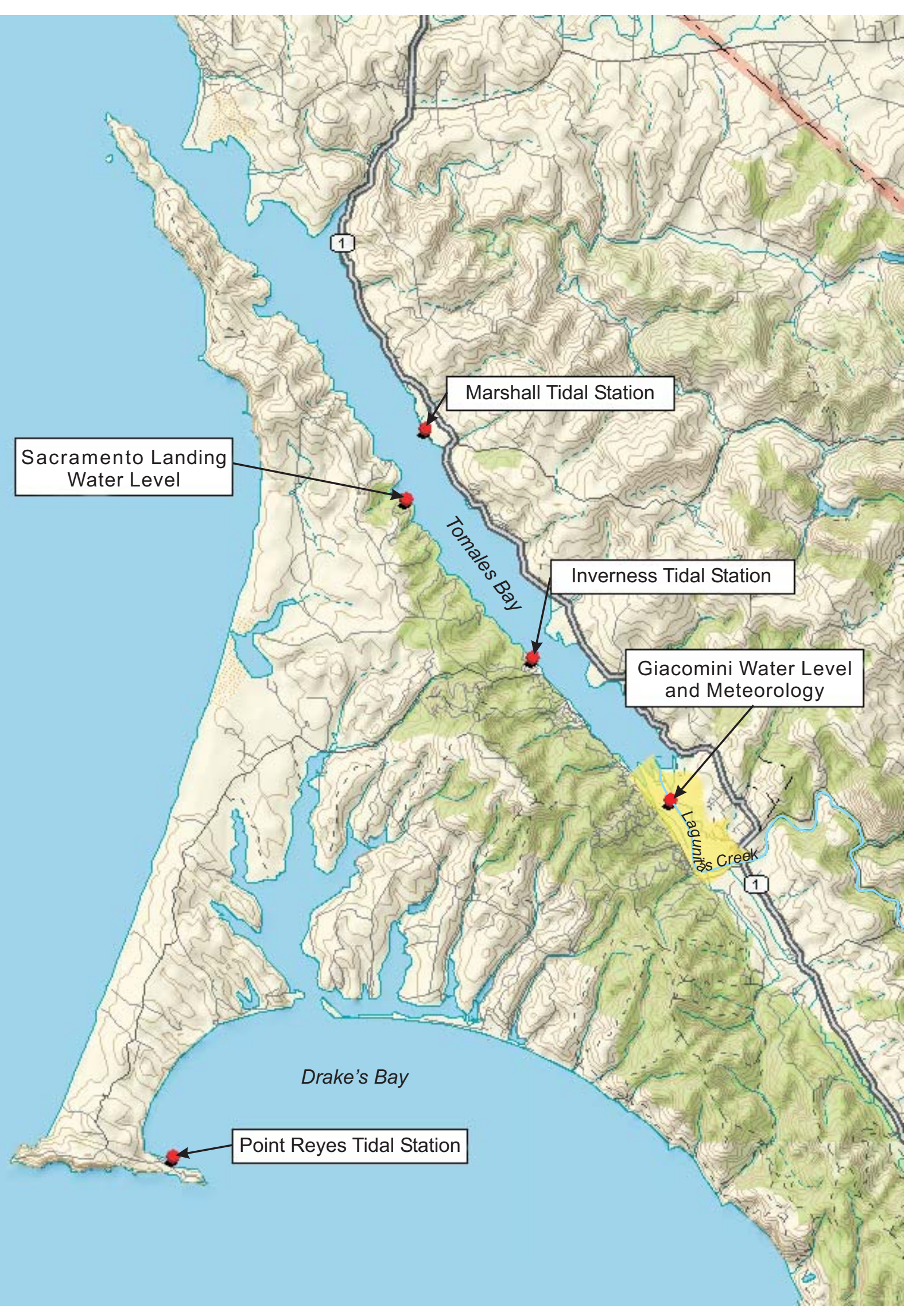

Figure 2 


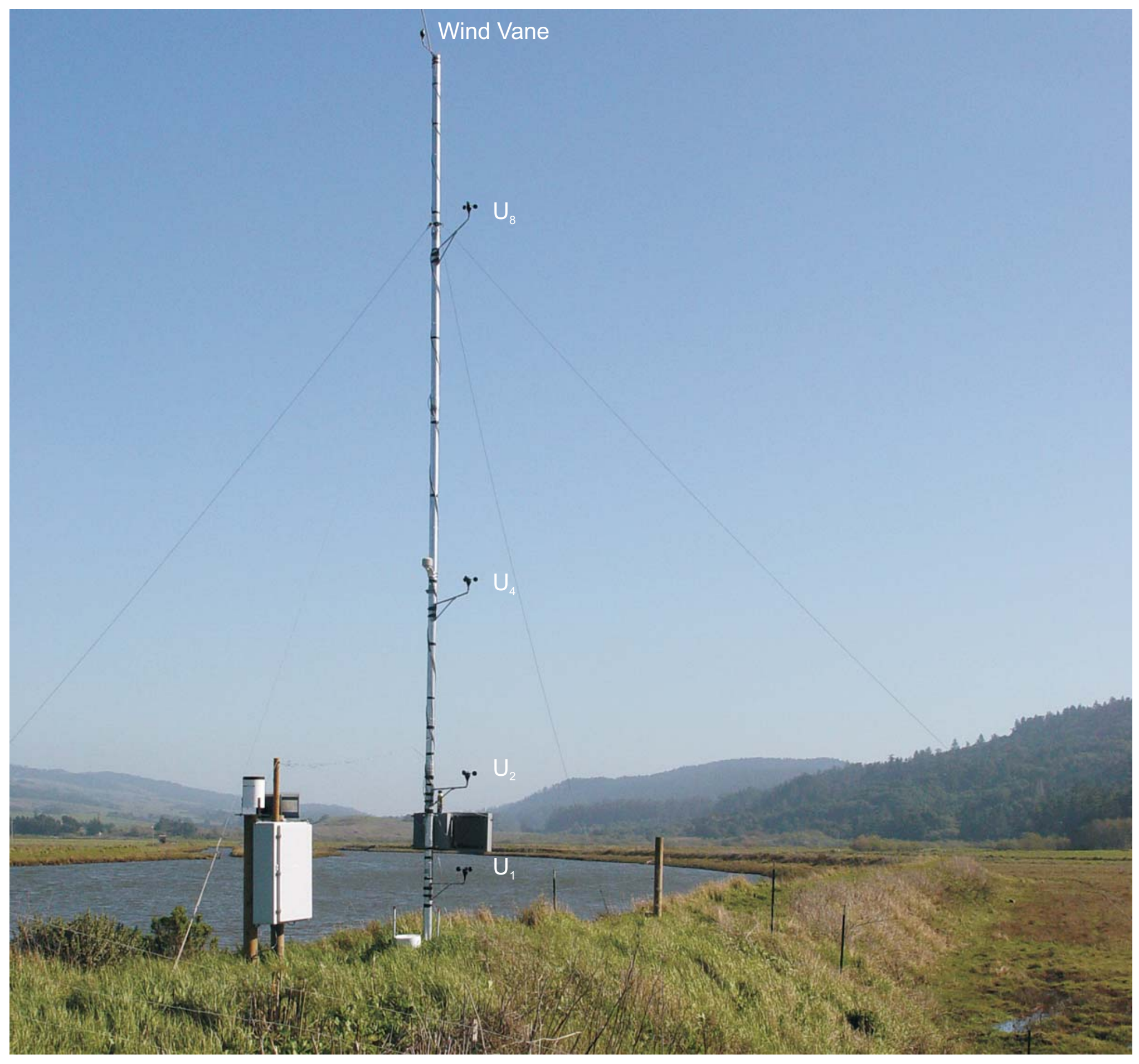

Figure 3 


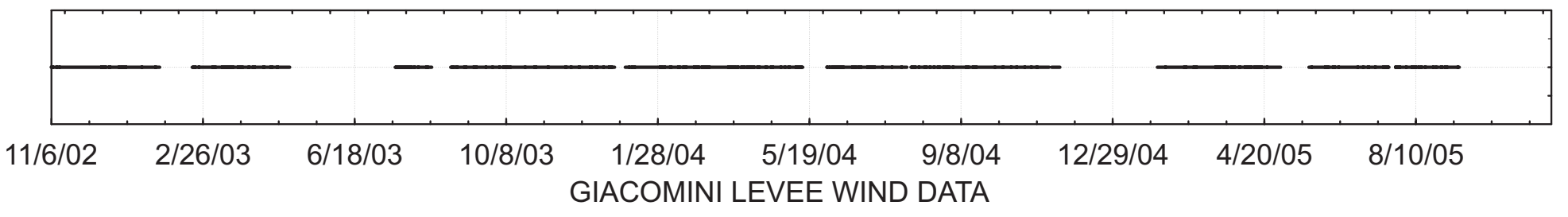

Figure 4 

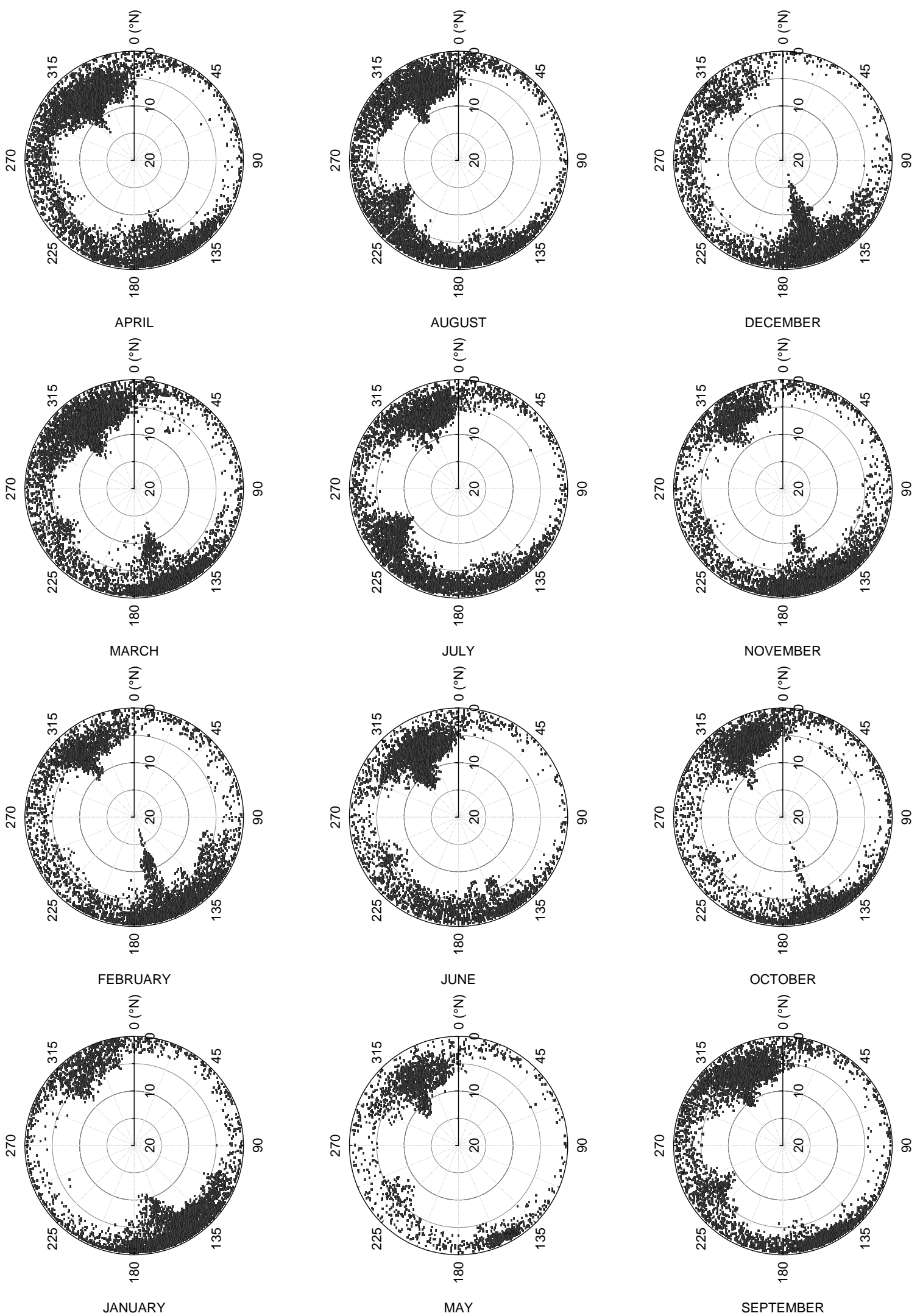

Figure 5 


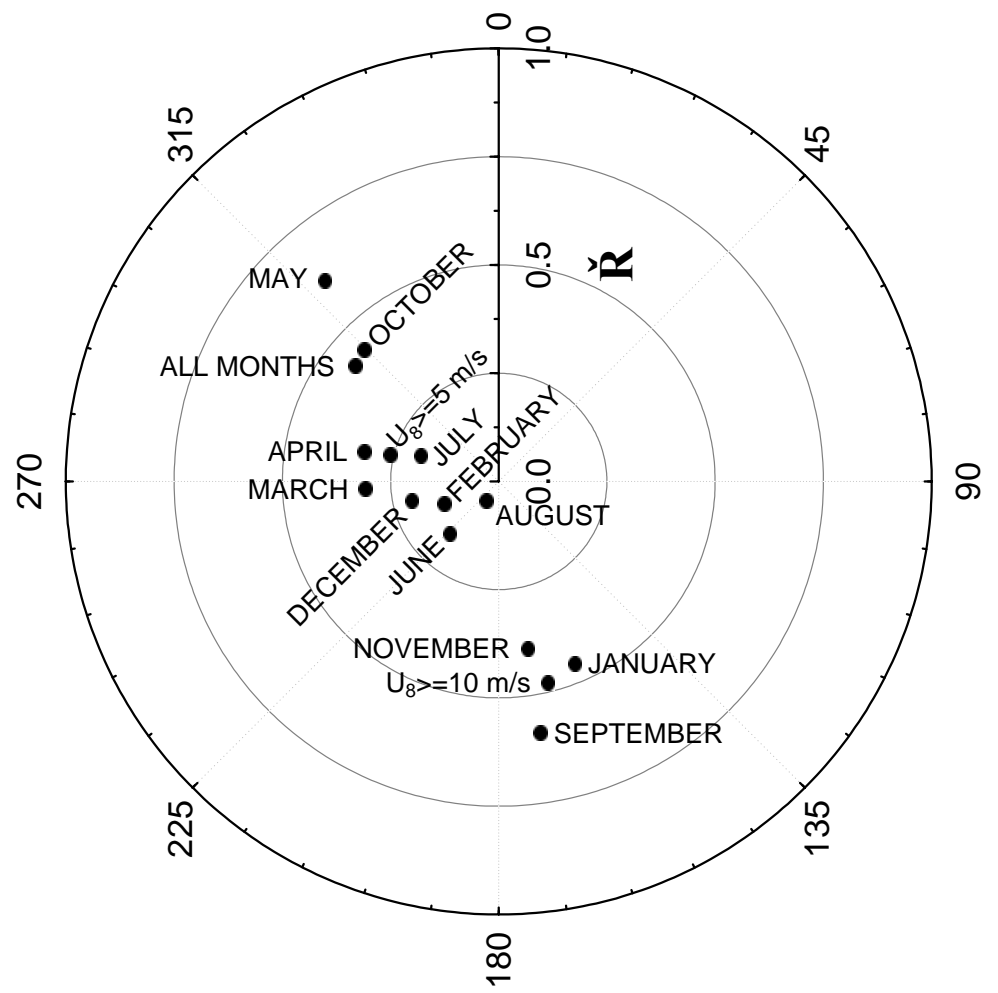

Figure 6 

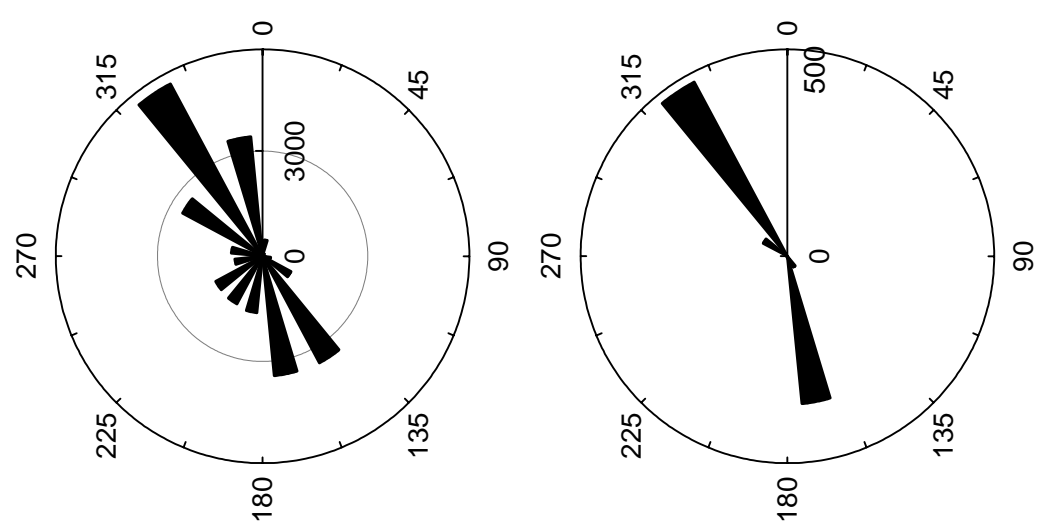

$2<U_{8}<=5 \mathrm{~m} / \mathrm{s}$

$10<U_{8} \mathrm{~m} / \mathrm{s}$
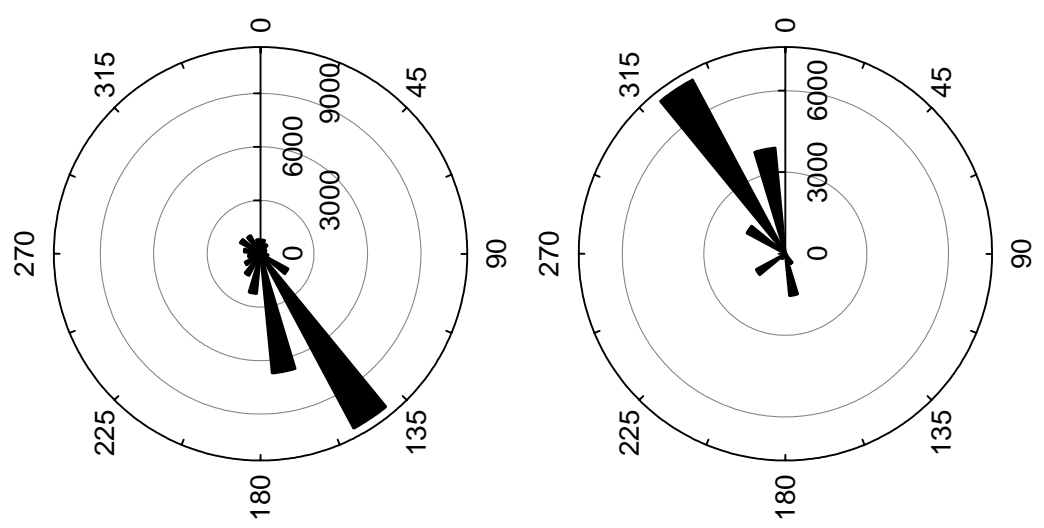

$\mathrm{U}_{8}<=2 \mathrm{~m} / \mathrm{s}$ $5<U_{8}<=10 \mathrm{~m} / \mathrm{s}$

Figure 7 


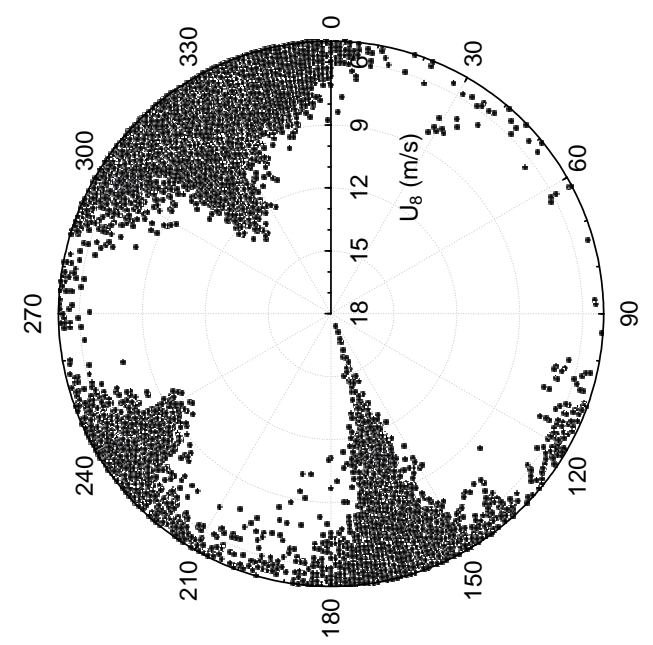

$\mathrm{U}_{8}>=5 \mathrm{~m} / \mathrm{s}$

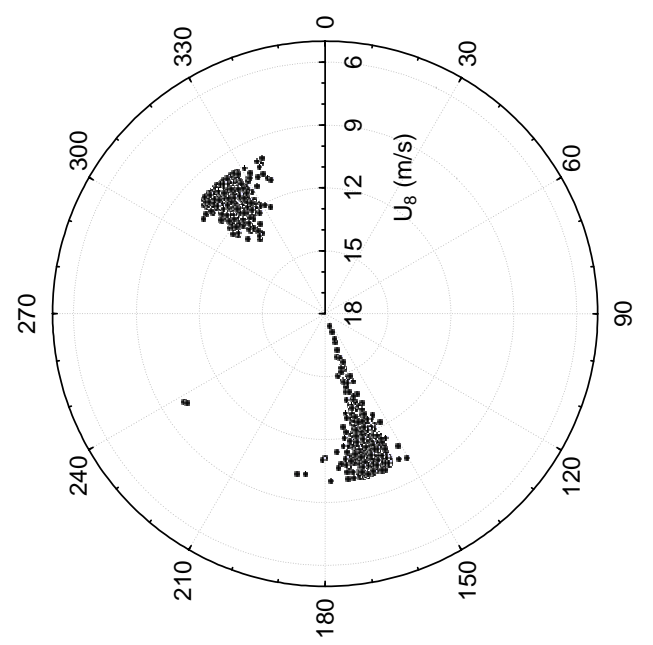

$\mathrm{U}_{8}>=10 \mathrm{~m} / \mathrm{s}$

Figure 8 

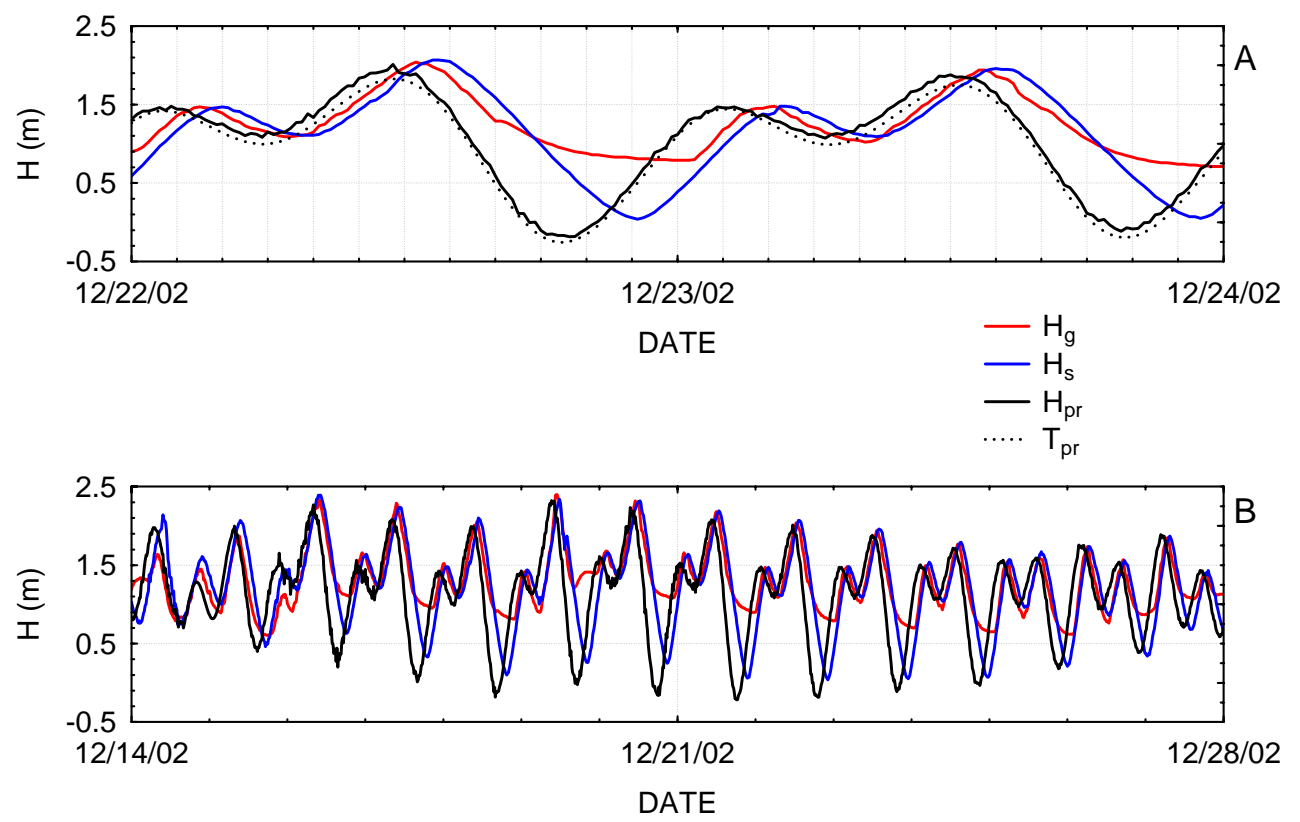

Figure 9 

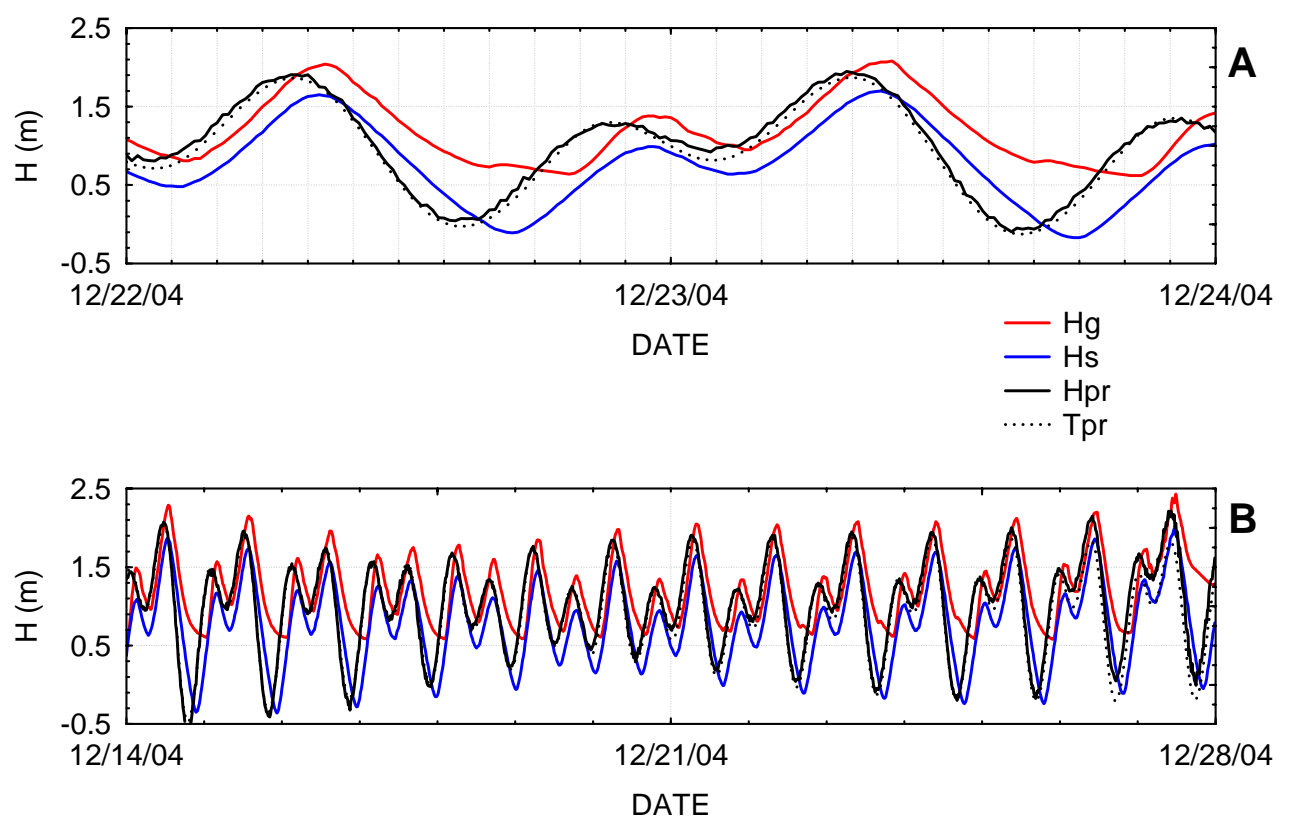

Figure 10 


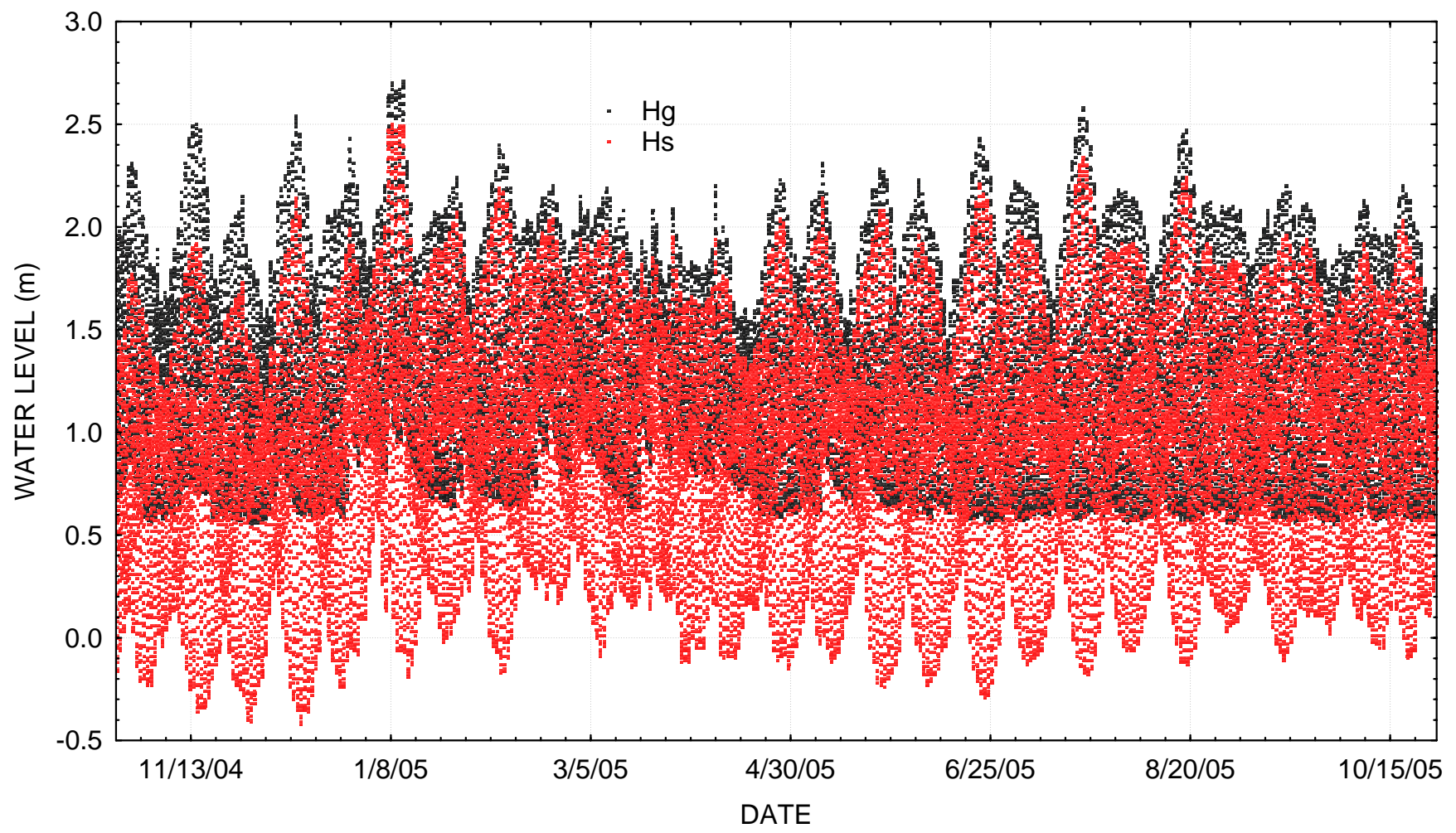

Figure 11 


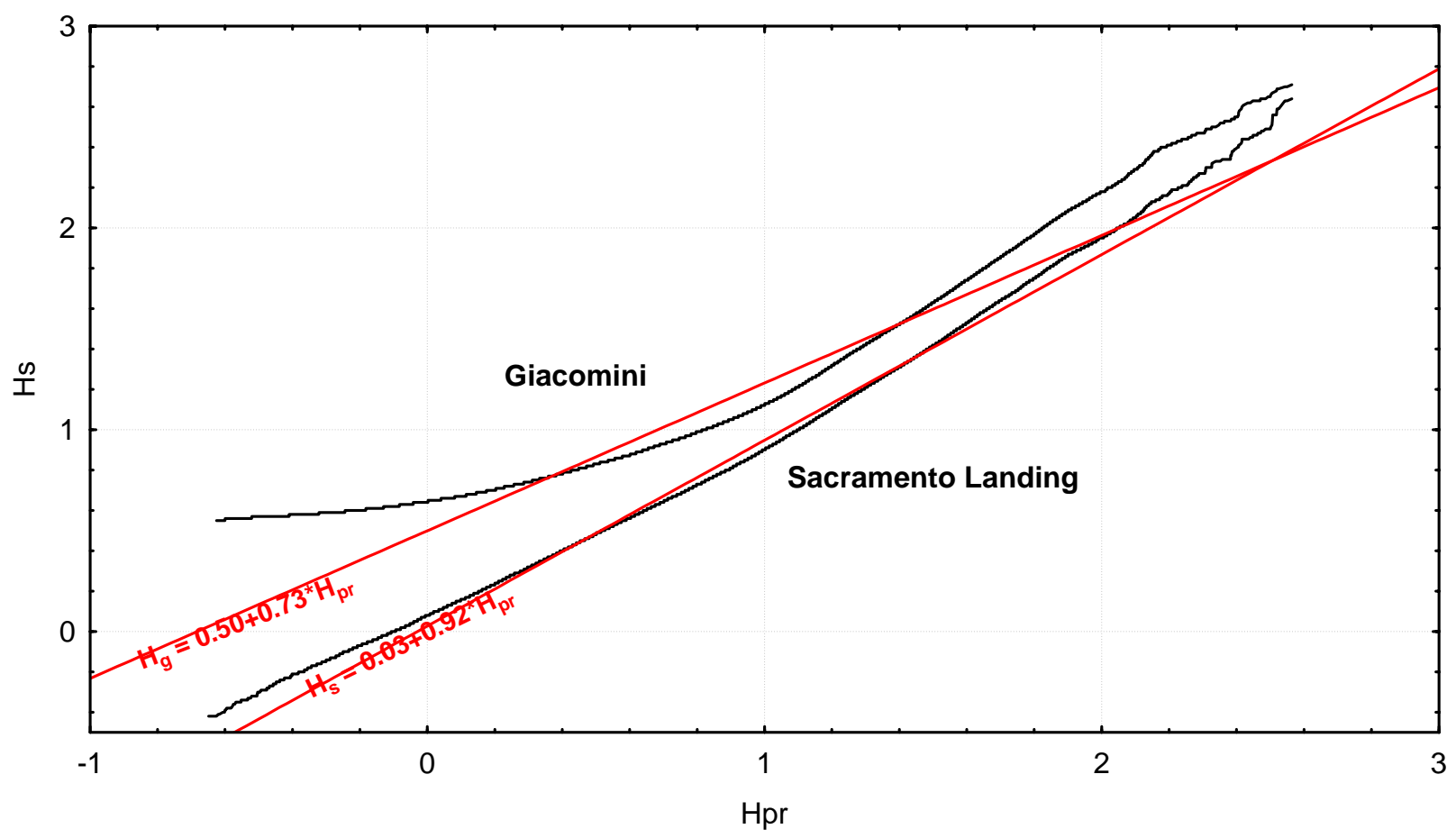

Figure 12 


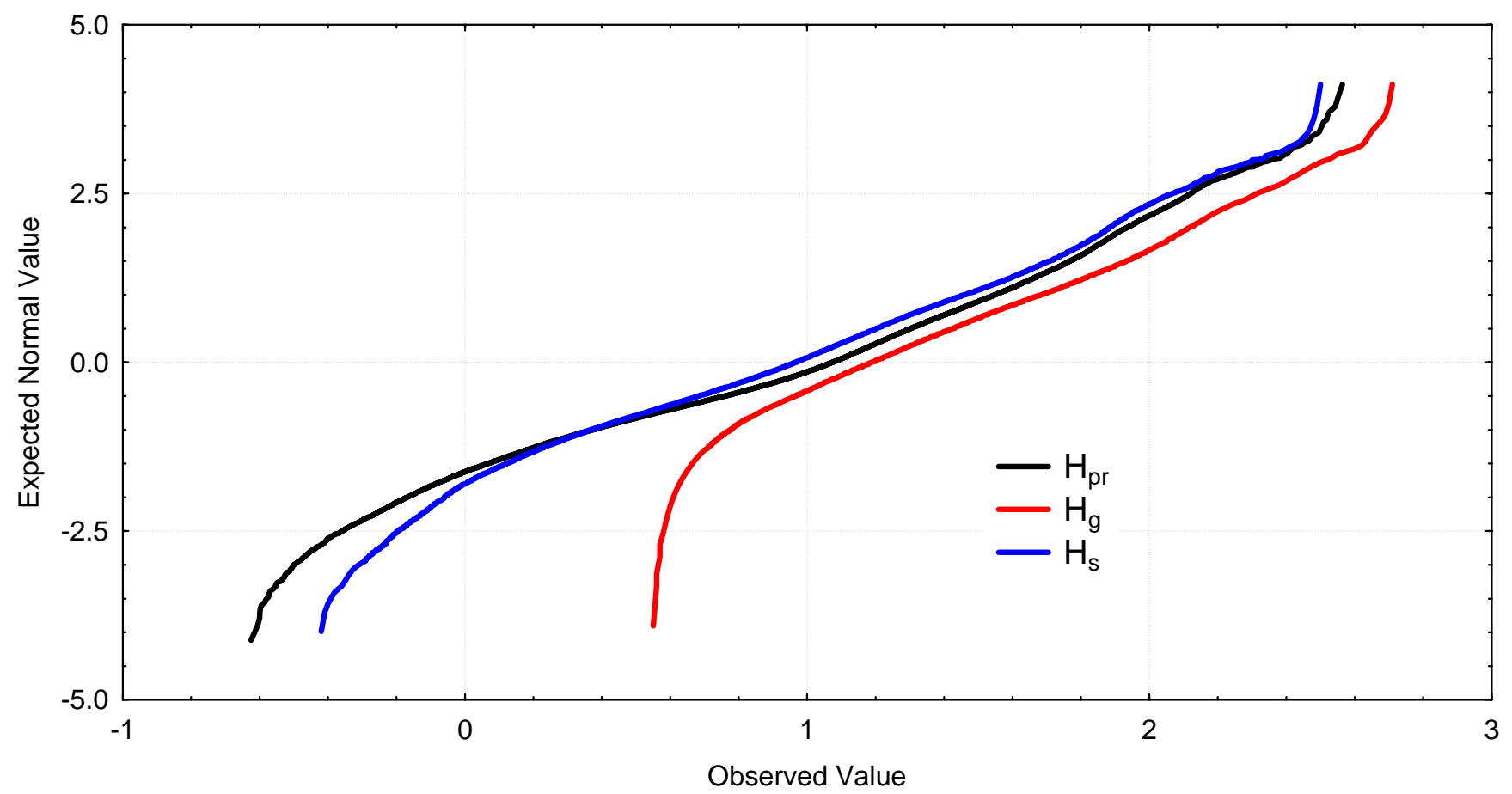

Figure 13 


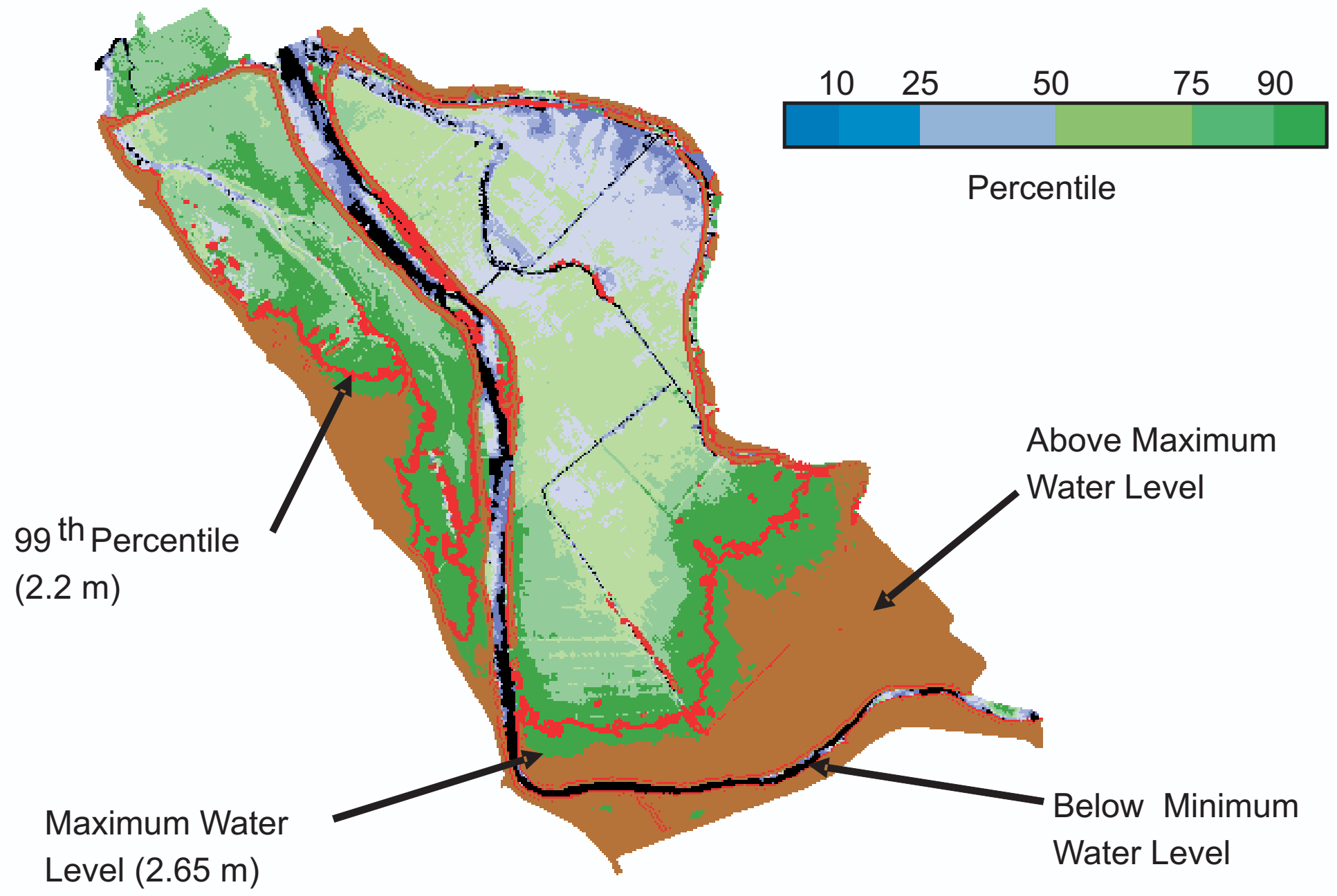

Figure 14 


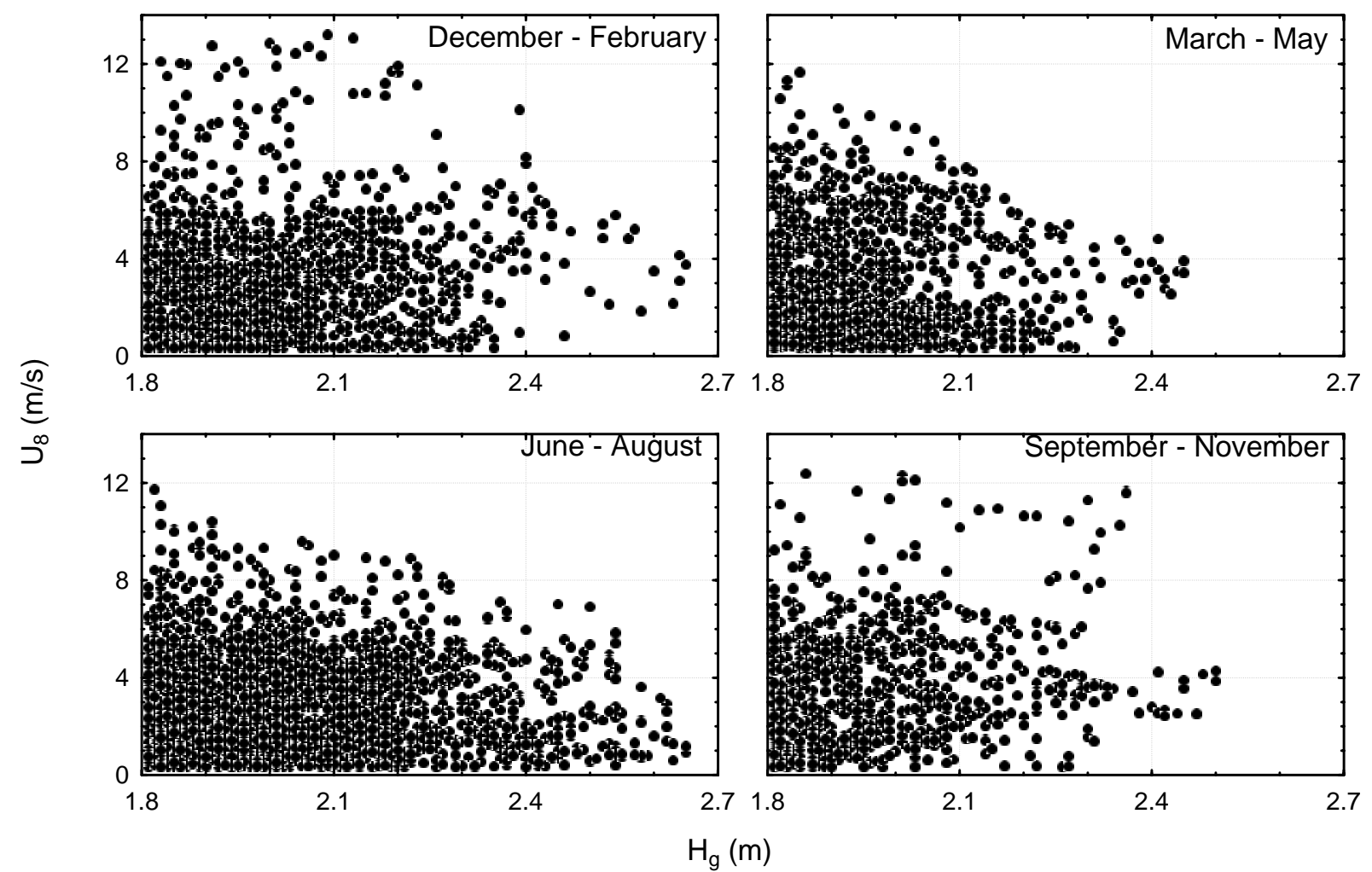

Figure 15 